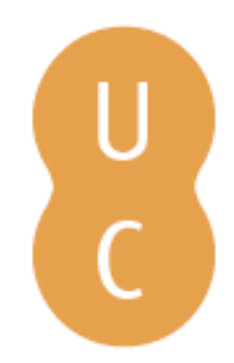

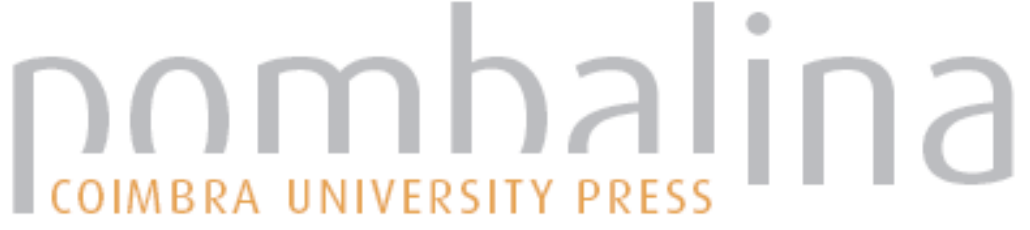

\section{Degradation of buried DNA samples in different types of soil}

Autor(es): $\quad$ Bogas, V.; Carvalho, M.; Anjos, M. J.; Pinheiro, M. F.; Corte-Real, F.

Publicado por: Imprensa da Universidade de Coimbra; International Academy of Legal

URL

persistente: URI:http://hdl.handle.net/10316.2/31774

DOI: $\quad$ DOI:http://dx.doi.org/10.14195/978-989-26-0173-1_25

Accessed : $\quad$ 26-Apr-2023 06:48:53

A navegação consulta e descarregamento dos títulos inseridos nas Bibliotecas Digitais UC Digitalis, UC Pombalina e UC Impactum, pressupõem a aceitação plena e sem reservas dos Termos e Condições de Uso destas Bibliotecas Digitais, disponíveis em https://digitalis.uc.pt/pt-pt/termos.

Conforme exposto nos referidos Termos e Condições de Uso, o descarregamento de títulos de acesso restrito requer uma licença válida de autorização devendo o utilizador aceder ao(s) documento(s) a partir de um endereço de IP da instituição detentora da supramencionada licença.

Ao utilizador é apenas permitido o descarregamento para uso pessoal, pelo que o emprego do(s) título(s) descarregado(s) para outro fim, designadamente comercial, carece de autorização do respetivo autor ou editor da obra.

Na medida em que todas as obras da UC Digitalis se encontram protegidas pelo Código do Direito de Autor e Direitos Conexos e demais legislação aplicável, toda a cópia, parcial ou total, deste documento, nos casos em que é legalmente admitida, deverá conter ou fazer-se acompanhar por este aviso.

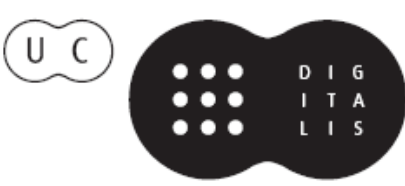




\section{Duarte Nuno Vieira Anthony Busuttil \\ Denis Cusack • Philip Beth}
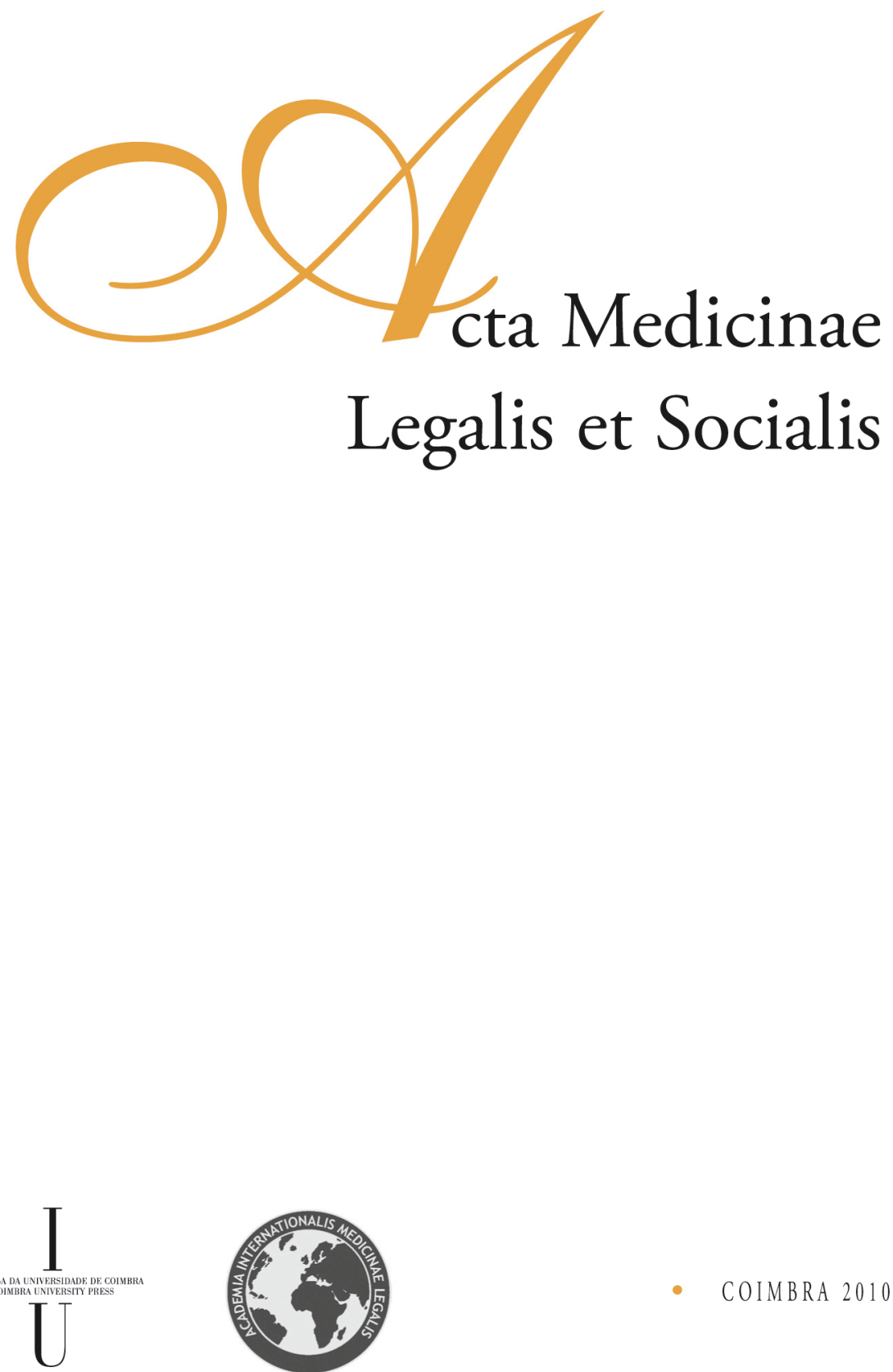
V. Bogas ${ }^{1}$, M. Carvalho ${ }^{1}$, M. J. Anjos ${ }^{1}$, M. F. Pinheiro' ${ }^{2,3,4}$, F. Corte-Real ${ }^{5,6}$

${ }^{1}$ Genetic Forensic Service Centre Branch of National Institute of Legal Medicine, Coimbra, Portugal

${ }^{2}$ Genetic Forensic Service North Branch of National Institute of Legal Medicine, Oporto, Portugal

${ }^{3}$ Faculty of Health Sciences of University Fernando Pessoa, Oporto, Portugal

${ }^{4}$ Faculty of Biomedical Sciences "Abel Salazar", Oporto, Portugal

${ }^{5}$ Centre Branch of National Institute of Legal Medicine, Coimbra, Portugal

${ }^{6}$ Faculty of Medicine, University of Coimbra, Portugal

\title{
DEGRADATION OF BURIED DNA SAMPLES IN DIFFERENT TYPES OF SOIL
}

\begin{abstract}
Biological samples buried in different types of soil are often found in crime scenes. These samples are usually highly degraded which difficult its analysis. Several factors contribute to the degradation of biological material including temperature variation, humidity, UV light and especially the presence of microorganisms.

Blood was collected to three non related male donors and blood stains were made in fabrics such as jeans, cotton and lycra. Blood stains were dried at room temperature and buried in three different types of soil, to promote its degradation.

It was found that samples suffer a high degradation over time which difficult their analysis. The marshy soil proved to be the most aggressive, leading to rapid degradation of the different analyzed fabrics, probably because of its high percentage of moisture and microbial proliferation.
\end{abstract}

\section{Introduction}

Biological samples buried in different types of soil are often found in crime scenes. These samples are usually highly degraded which difficult its analysis. Several factors contribute to the degradation of biological material including temperature variation, humidity, UV light and especially the presence of microorganisms.

The cellular post-mortem degradation starts with the autolysis of the cell membrane. As a consequence the DNA is released to the environment and once in the soil it can 1) connect to minerals and humic substances such as humic acid (HA), 2) be degraded by bacterial DNases and used as nutrients for growth of plants and microorganisms or 3) be incorporated into the bacterial genome.

The preservation of DNA from buried samples is influenced by physical, chemical and biological properties of DNA and soil, such as $\mathrm{pH}$, moisture percentage, concentration of humic substances, mineral content and cation concentration, and is dependent on its connection to certain minerals, humic substances and organomineral complexes.

The increase of humidity percentage leads to an increase in the number of microorganisms and consequently to a higher DNase activity. Another factor which affects the DNA degradation rate is temperature: whenever it rises, the half-life time of DNA decreases, as a consequence of increased activity of DNases [1, 2, 3]. 


\section{Materials and Methods}

$18 \mathrm{ml}$ of blood were collected from three non related male donors and 36 blood stains with approximately $7 \mathrm{~cm}$ of diameter were made in three different fabrics such as jeans, cotton and lycra, previously washed and decontaminated for 20 minutes with UV light. Blood stains were dried during 3 days at room temperature before being buried in three different types of soil (sand, marsh and clay).

Small pieces of each stain $\left(12,5 \mathrm{~cm}^{2}\right)$ were collected after 15,30 and 90 days. At this time, day, hour, place, presence of vegetation, temperature and humidity were registered. Photographic registration of the places and stains were also obtained, as well as, graphical registers from the closest meteorological stations, such as temperature, pressure, humidity and rainfall of the 31 days that precedes the collection. The different soils were also chemically characterized (Table 1).

Positive controls (blood stains of each individual) were made in all types of fabric. All fragments, as well as the control samples, were properly conditioned and frozen at $-80^{\circ} \mathrm{C}$ until its analysis.

DNA extraction was performed using Chelex 100 method [4], QIAmp Investigator kit (Qiagen) and DNA IQ ${ }^{\mathrm{TM}}$ System kit (Promega). Samples were quantified with Human Quantifiler ${ }^{\mathrm{TM}}$ kit (Applied Biosystems), according to manufacturer's instructions using an ABI Prism® 7000 (real-time PCR).

\section{Results}

After ninety days jeans and cotton fabrics buried in marshy soil disappeared (Figures 1 and 3). Since only lycra remained in this type of soil for so long (Figure 2), it seems that this is a highly resistant fabric. Despite of its resistance, the DNA in lycra fabric undergoes a high degradation, not allowing its analysis.

In spite of the fabrics buried in the other types of soil didn't disappear after ninety days (Figures 4 to 9), quantification results after 15, 30 and 90 days, showed a high DNA degradation rate over time.

The greater quantity of DNA was obtained with samples buried during 15 and 30 days in sandy soil, extracted with QIAmp Investigator kit (Table 2).

\section{Discussion}

It was found that samples suffer a high degradation overtime which difficult their analysis. The marshy soil proved to be the most aggressive, leading to rapid degradation of the different analyzed fabrics, probably because of its high percentage of moisture and microbial proliferation, which are also responsible for the extensive DNA degradation verified after 15 days. The sandy soil with the highest $\mathrm{pH}$ showed the lowest degradation rate.

\section{Conclusion}


It is important to continue seeking for new methods of DNA extraction as well as improve the existing ones, to enable recover even the smallest amount of DNA present in degraded samples.

\section{References}

[1]. LEVY-BOOTH D., CAMPBEll R., GULDEN R., HART M., POWELl J., KLIRONOMOS J., PAULS K., SWANTON CLARENCE J., TREVORS J., DUNFIELD K.; "Cycling of extracellular DNA in the soil environment"; Soil Biol Biochem; Vol. 39, pp. 2977-2991, 2007.

[2]. BLUM S.A.E., LORENZ M.G., WACKERNAGEL W.;"Mechanism of retarded DNA degradation and prokaryotic origin of DNases in nonsterile soils"; Syst. Appl. Microbiol.; Vol 20, pp. 513-521, 1997.

[3]. GREAVES M.P., WILSON M.J.; "The degradation of nucleic acids and montmorillonitenucleic-acid complexes by soil microorganisms"; Soil Biol. Biochem.; Vol 2, pp. 257-268, 1970.

[4]. WALSH P.S., METZGER D.A., HIGUCHI R.; "Chelex 100 as a medium for a simple extraction of DNA for PCR-based typing from a forensic material"; Biotechniques; Vol 10, pp. 506-513, 1991.

\begin{tabular}{|c|c|c|c|c|c|c|c|c|c|c|c|c|c|}
\hline Samples & $\mathrm{SiO} 2(\%)$ & Al2O3 (\%) & $\mathrm{CaO}(\%)$ & MgO (\%) & $\mathrm{Na} 2 \mathrm{O}(\%)$ & K2O (\%) & $\mathrm{Fe} 2 \mathrm{O3}(\%)$ & P2O5 (\%) & ТіОз (\%) & $\mathrm{Mn}(\mathrm{ppm})$ & $\mathrm{Cu}(\mathrm{ppm})$ & $\mathrm{Zn}(\mathrm{Ppm})$ & $\mathrm{pH}$ \\
\hline Marshy soil & 55,14 & 17,56 & 4,12 & 2,57 & 1,07 & 1,63 & 3,53 & 0,65 & 0,80 & 978 & 27,1 & 160 & 5,91 \\
\hline Sandy soil & 68,32 & 8,66 & 7,51 & 1,05 & 0,89 & 1,12 & 1,24 & 0,09 & 1,23 & 234 & 12,6 & 71 & 6,84 \\
\hline Claysoil & 54,63 & 20,31 & 2,13 & 1,54 & 0,84 & 1,72 & 4,96 & 0,56 & 0,78 & 563 & 32,1 & 97 & 5,80 \\
\hline
\end{tabular}

Table 1 - Chemical characterization of the different soils 


\begin{tabular}{|l|c|c|c|}
\hline \multicolumn{4}{|c|}{15 days - Extraction with QIAmp } \\
\hline & Soil & Quantification & IPC \\
\hline N. Denim & Sand & 0.8705 & 31.26 \\
\hline N. Lycra & Sand & 0.7747 & 32.04 \\
\hline N. Cotton & Sand & undetermined & 31.44 \\
\hline A. Denim & Sand & undetermined & $*$ \\
\hline A. Lycra & Sand & 2,625 & 30.01 \\
\hline A. Cotton & Sand & 0.0053 & $*$ \\
\hline P. Denim & Sand & 0.0134 & $*$ \\
\hline P. Lycra & Sand & 2,282 & 31.04 \\
\hline P. Cotton & Sand & 2,793 & 30.47 \\
\hline
\end{tabular}

\begin{tabular}{|l|c|c|c|}
\hline \multicolumn{4}{|c|}{ 30 days - Extraction with QIAmp } \\
\hline & Soil & Quantification & IPC \\
\hline N. Denim & Sand & undetermined & und \\
\hline N. Lycra & Sand & undetermined & und \\
\hline N. Cotton & Sand & 0.0026 & $*$ \\
\hline A. Denim & Sand & 0.004 & $*$ \\
\hline A. Lycra & Sand & 1,9384 & 30.35 \\
\hline A. Cotton & Sand & 0.0038 & 35.02 \\
\hline P. Denim & Sand & 0.0082 & $*$ \\
\hline P. Lycra & Sand & 0.0659 & 36.54 \\
\hline P. Cotton & Sand & undetermined & und \\
\hline
\end{tabular}

\begin{tabular}{|l|l|c|c|}
\hline N. Denim & Clay & undetermined & 39.32 \\
\hline N. Lycra & Clay & undetermined & $*$ \\
\hline N. Cotton & Clay & 0.0101 & $*$ \\
\hline A. Denim & Clay & undetermined & $*$ \\
\hline A. Lycra & Clay & 0,0117 & $*$ \\
\hline A. Cotton & Clay & undetermined & $*$ \\
\hline P. Denim & Clay & undetermined & $*$ \\
\hline P. Lycra & Clay & $\mathbf{0 . 0 0 6 5}$ & $*$ \\
\hline P. Cotton & Clay & ind & 30.89 \\
\hline
\end{tabular}

\begin{tabular}{|l|l|c|c|}
\hline N. Denim & Clay & 0.0055 & $*$ \\
\hline N. Lycra & Clay & 0.0129 & $*$ \\
\hline N. Cotton & Clay & 0.0083 & $*$ \\
\hline A. Denim & Clay & 0.0018 & $*$ \\
\hline A. Lycra & Clay & 0.0037 & $*$ \\
\hline A. Cotton & Clay & undetermined & $*$ \\
\hline P. Denim & Clay & 0.0113 & $*$ \\
\hline P. Lycra & Clay & 0.008 & $*$ \\
\hline P. Cotton & Clay & $\mathbf{0 . 0 0 3 5}$ & $*$ \\
\hline
\end{tabular}

\begin{tabular}{|l|l|c|c|}
\hline N. Denim & Marsh & 0,0112 & $*$ \\
\hline N. Lycra & Marsh & undetermined & 32,47 \\
\hline N. Cotton & Marsh & 0,002 & $*$ \\
\hline A. Denim & Marsh & undetermined & und \\
\hline A. Lycra & Marsh & undetermined & 30,47 \\
\hline A. Cotton & Marsh & undetermined & 32,98 \\
\hline P. Denim & Marsh & 0,0023 & $*$ \\
\hline P. Lycra & Marsh & undetermined & $*$ \\
\hline P. Cotton & Marsh & 0,0004 & und \\
\hline
\end{tabular}

\begin{tabular}{|l|l|l|c|}
\hline N. Denim & Marsh & undetermined & und \\
\hline N. Lycra & Marsh & undetermined & und \\
\hline N. Cotton & Marsh & undetermined & 30.19 \\
\hline A. Denim & Marsh & undetermined & und \\
\hline A. Lycra & Marsh & undetermined & 38.76 \\
\hline A. Cotton & Marsh & undetermined & und \\
\hline P. Denim & Marsh & undetermined & und \\
\hline P. Lycra & Marsh & undetermined & und \\
\hline P. Cotton & Marsh & undetermined & und \\
\hline
\end{tabular}

Table 2 - Quantification results of samples buried in the different soils for 15 and 30 days. N., A., and P. correspond to the blood donors. IPC values: und - undeterminated; * ${ }^{*}$ normal $(<30)$

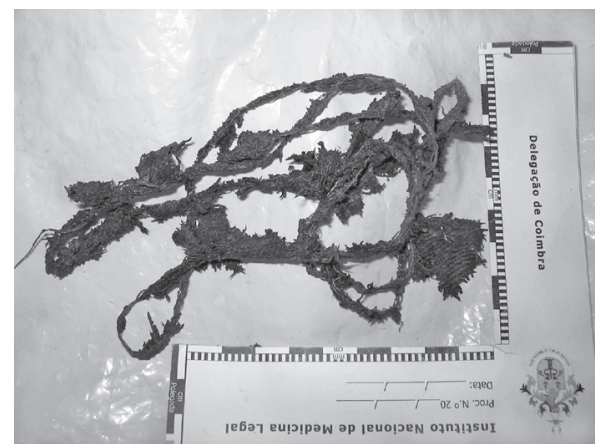

Figure 1 - Denim 90 days in marshy soil

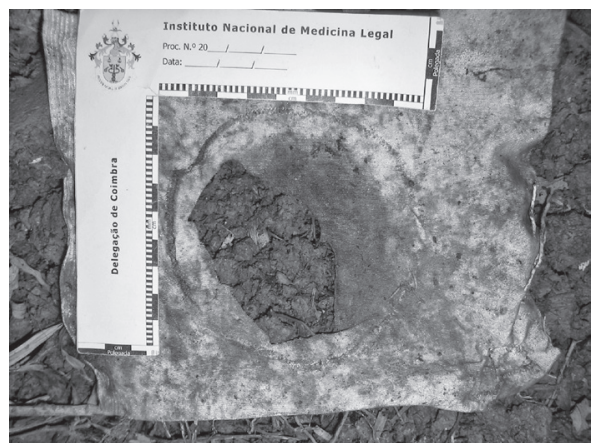

Figure 2 - Lycra 90 days in marshy soil 


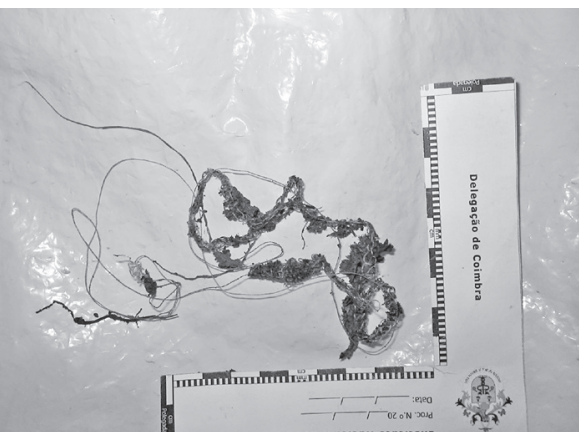

Figure 3 - Cotton 90 days in marshy soil

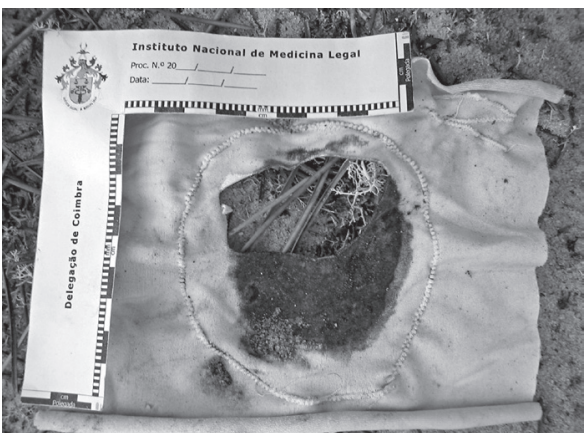

Figure 5 - Lycra 90 days in sandy soil

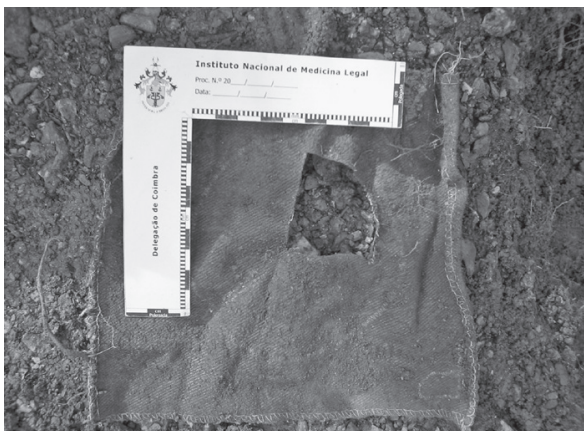

Figure 7 - Denim 90 days in clay soil

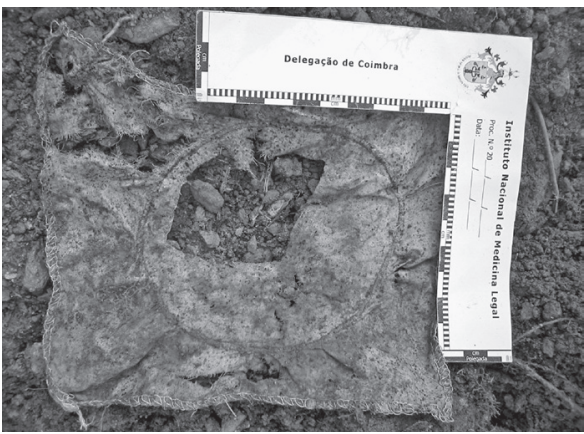

Figure 9 - Cotton 90 days in clay soil

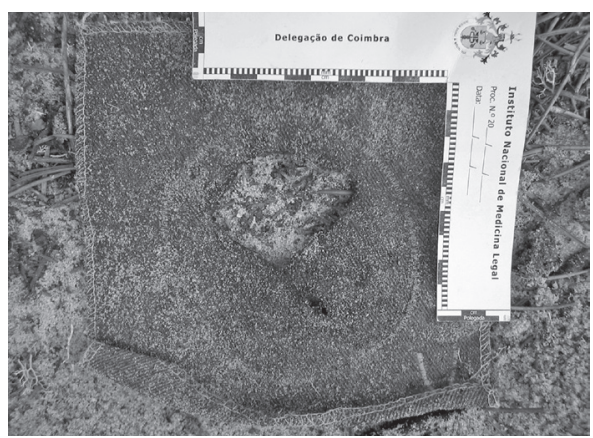

Figure 4 - Denim 90 days in sandy soil

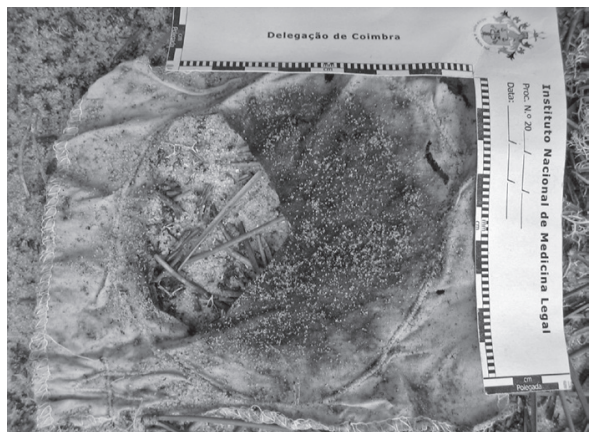

Figure 6 - Cotton 90 days in sandy soil

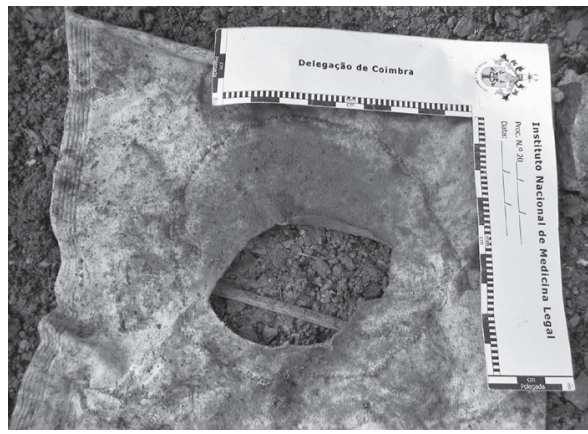

Figure 8 - Lycra 90 days in clay soil 